DOI: 10.17707/AgricultForest.63.1.12

\author{
Reşat DEGIRMENCI, \\ Huseyin VAROGLU, Lutfi TAHTACIOGLU ${ }^{I}$
}

\title{
DETERMINATION OF SOME BARLEY (Hordeum vulgare L.) VARIETIES SUITABLE FOR CYPRUS ECOLOGICAL CONDITIONS
}

\section{SUMMARY}

This research was carried out on 6 barley varieties (two-rowed; Otis, Nure, Pewter Fouga, Prestige and six rowed; Athenais) in a Randomized Complete Block Design with three replications in 2008-2009 growing season in Cyprus; Turkmenkoy, Kumkoy, Tepebas and Haspolat locations. It was determined that the effects of genotype, environment and genotype $\mathrm{x}$ environment interaction were significant at $1 \%$ level of probability for grain yield. Grain yield varied from $61.0-410.5 \mathrm{~kg} / \mathrm{da}$. Kumkoy location had the highest grain yield $(303.7 \mathrm{~kg} / \mathrm{da})$ while Turkmenkoy location had the lowest grain yield $(118.3 \mathrm{~kg} / \mathrm{da})$. While, cultivars Nure and Pewter had the highest yield ( 250.0 and $261.4 \mathrm{~kg} / \mathrm{da}$ ), cultivars Fouga and Prestige had the lowest grain yield (156.3 and $158.0 \mathrm{~kg} / \mathrm{da}$ ) for all environments. While the highest grain yield is found in Kumkoy location with Nure $(410 \mathrm{~kg} / \mathrm{da})$ and Pewter $(400 \mathrm{~kg} / \mathrm{da})$, Turkmenkoy location has the lowest grain yield with Fouga $(61 \mathrm{~kg} / \mathrm{da})$ variety.

Keywords: barley, location, grain yield, cultivars

\section{INTRODUCTION}

Cyprus is the third largest island in the North East of the Mediterranean Sea with $9251 \mathrm{~km}^{2}$ area. However; the area of Northern Cyprus is $3298 \mathrm{~km}^{2}$. By looking at the geographical location of the island; there are Besparmak Mountains which forms the Turkish side of the island and range from east to the west. Trodos Mountains on the other hand form the Greek side of the island and range on the middle part. There is arid Mesarya lowland between these two mountains and most of this part is this lowland. The western part of this region is called West Mesarya Lowland which is arable for irrigated farming as a result of groundwater springs in that region whereas on the East Mesarya dry farming is held mostly.

On the island where typical Mediterranean climate reigns over, the average precipitation is between $350-400 \mathrm{~mm} /$ year as well as altering per years. Precipitation is generally in dense in December-May (Statistics and Planning Division, 2011).

\footnotetext{
${ }^{1}$ Reşat Degirmenci (corresponding author: rdeirmenci@yahoo.com), Huseyin Varoglu The Ministry of Food, Agriculture and Energy, Agricultural Research Institute, CYPRUS, Lufti Tahtacioglu Crop Husbandry Technical Assistance Team, CYPRUS

Paper presented at the $7^{\text {th }}$ International Scientific Agricultural Symposium "AGROSYM 2016".

Notes: The authors declare that they have no conflicts of interest. Authorship Form signed online.
} 
134.3 million tons of barley is produced on 48.6 million hectare area in the world. The yield per decare is $276.3 \mathrm{~kg}$ In Turkey, the barley cultivation area is 3.4 million hectares and production amount is 7.6 million tons. Yield per decare is $232.0 \mathrm{~kg}$ and it is the second after wheat in grains (FAO, 2011). In North Cyprus, there is 124,000 ha cultivation area existing and Grain is cultivated in 84,000 ha area which corresponds to this land's \%65-70. The largest share is barley $(58,325 \mathrm{ha})$ with \%93 ratio in grain lands then respectively wheat (4046 ha) with \%6.5 ratio, oat (530 ha) with \%1 ratio (Statistics and Planning Division, 2010).

The demand for barley has been increasing day by day which has a large usage area in feed and food industry. Although the livestock industry has improved in the country, the dry farming has spotlighted the barley due to insufficient pasture areas, limited water and precipitation and inability to cultivate roughage.

The barley cultivation area of North Cyprus is 80.7 thousand hectare and yield per decare is $208 \mathrm{~kg}$ which means below the average of Turkey and the world. This amount is not sufficient for the country and 51.000 tons of barley is imported average per year (Statistics and Planning Branch, 2011).

As being unable to increase the current cultivation sites; increasing the production amount from unit site is important and the variable to be used will contribute most importantly. In this study barley varieties which origin from Italy, France and Greece is tested in 4 different locations of Cyprus in terms of yield capability.

\section{MATERIALS AND METHODS}

This study is held in the producer lands of 4 different locations (West Mesarya-Kumkoy, North Coast- Tepebasi, Middle Mesarya- Haspolat, EastMesarya- Turkmenkoy) which represent different conditions of North Cyprus in 2008-2009 within the conditions without irrigation. 6 barley cultivars are used in the experiment and related information is given in Table 1.

Table 1.Information related to Barley varieties used in the Experiment

\begin{tabular}{|c|c|c|}
\hline Cultivar Name & Country of Origin & Row Number \\
\hline Athenais & Greece & 6 \\
\hline Pewter & Greece & 2 \\
\hline Otis & Italy & 2 \\
\hline Nure & Italy & 2 \\
\hline Prestige & France & 2 \\
\hline Fouga & France & 2 \\
\hline
\end{tabular}

Areal precipitation per month, average relative humidity and average temperature per month related to the production years are given on Table 2. The soil types are different where the experiments were held and its characteristic features are given on Table 3 . 
Table 2. Climate Data related to 2008-2009 years

\begin{tabular}{|c|c|c|c|c|c|c|c|c|c|c|}
\hline \multicolumn{11}{|c|}{ Months } \\
\hline \multirow{5}{*}{$\begin{array}{c}\text { Avarege } \\
\text { temperat } \\
\text { ure }\left(\mathbf{C}^{0}\right)\end{array}$} & & Nov & Dec & Jan & Feb & March & April & May & June & $\begin{array}{c}\text { Period } \\
\text { aver/ } \\
\text { total }\end{array}$ \\
\hline & Turkmenkoy & 17.2 & 11.9 & 16.6 & 17.0 & 18.8 & 24.6 & 28.7 & 34.6 & 21.2 \\
\hline & Tepebaş1 & 18.2 & 13.2 & 15.4 & 15.5 & 16.8 & 21.4 & 25.1 & 31.1 & 19.6 \\
\hline & Kumkoy & 18.4 & 13.6 & 16.8 & 16.5 & 17.9 & 22.6 & 26.0 & 31.6 & 20.4 \\
\hline & Haspolat & 17.4 & 12.0 & 11.3 & 11.6 & 12.2 & 17.1 & 21.8 & 28.1 & 16.4 \\
\hline \multirow{4}{*}{$\begin{array}{c}\text { Avarege } \\
\text { relative } \\
\text { humi } \\
\text { dity }(\%)\end{array}$} & Turkmenkoy & 64.0 & 67.7 & 72.0 & 76.3 & 70.7 & 62.0 & 51.9 & 44.2 & 63.6 \\
\hline & Tepebaş1 & 68.3 & 68.3 & 70.8 & 72.6 & 65.3 & 65.4 & 58.6 & 52.7 & 65.3 \\
\hline & Kumkoy & 59.8 & 59.8 & 66.7 & 69.7 & 65.5 & 62.7 & 57.6 & 52.8 & 61.8 \\
\hline & Haspolat & 63.4 & 67.7 & 71.6 & 78.3 & 70.1 & 61.7 & 50.9 & 41.6 & 63.2 \\
\hline \multirow{4}{*}{$\begin{array}{c}\text { Areal } \\
\text { Precipitat } \\
\text { ion }(\mathbf{m m})\end{array}$} & Turkmenkoy & 20.6 & 61.9 & 49.5 & 40.4 & 51.4 & 27.4 & 18.3 & 0.7 & 270.2 \\
\hline & Tepebaşı & 16.6 & 84.2 & 78.6 & 95.3 & 63.0 & 11.7 & 11.6 & 0 & 361.0 \\
\hline & Kumkoy & 2.8 & 67.7 & 79.8 & 93.7 & 57.7 & 15.5 & 10.5 & 0 & 327.7 \\
\hline & Haspolat & 9.2 & 49.3 & 41.3 & 28.9 & 40.1 & 22.5 & 9.4 & 0 & 200.7 \\
\hline
\end{tabular}

Table 3. Soil Characteristics of Lands where the experiments were established

\begin{tabular}{|c|c|c|c|c|c|}
\hline Location & $\mathbf{p H}$ & $\begin{array}{c}\text { Lime } \\
(\boldsymbol{\%})\end{array}$ & $\begin{array}{c}\text { Total } \\
\text { Salt (\%) }\end{array}$ & $\begin{array}{c}\text { Organic } \\
\text { substance (\%) }\end{array}$ & Texture \\
\hline Tepebas1 & 7.4 & 22.0 & 0.06 & 2.30 & Sandy-Loam \\
\hline Turkmenkoy & 7.8 & 36.6 & 0.05 & 1.22 & Sandy-Loam \\
\hline Kumkoy & 7.3 & 14.1 & 0.05 & 1.30 & Loamy-Sand \\
\hline Haspolat & 7.5 & 22.0 & 0.28 & 1.68 & $\begin{array}{c}\text { Argillaceous- } \\
\text { Loam }\end{array}$ \\
\hline
\end{tabular}

The experiments were established in 3 replications according to Randomized Complete Block Design. The planting was done in parcels with 1.2 $\mathrm{m}$ width and $5 \mathrm{~m}$ height to have 500 seeds per $\mathrm{m}^{2}$. Each parcel included 6 plant lines with $20 \mathrm{~cm}$ gaps. The parcels were dressed according to $8 \mathrm{~kg} / \mathrm{da}$ pure $\mathrm{N}$ and $5 \mathrm{~kg} / \mathrm{da} \mathrm{P}_{2} \mathrm{O}_{5} / \mathrm{da}$. The half of the Nitrogen and total Phosphorus was applied during the plantation and the remaining half of the Nitrogen will be applied at the beginning of bolting. In full-fledging period; from the sides of parcels 1 line each and from the parcel heads $50 \mathrm{~cm}$ each were cut and the remaining parts were harvested and blended by parcel combine harvester. The data obtained from the experiment were analyzed by JMP statistical package program and the differences in averages were compared by LSD test.

\section{Turkmenkoy}

\section{RESULT AND DISCUSSION}

The plantation of the experiment was done on 19.12.2008 with a grain drill. The experiment was established on a land where the organic substance and productivity is low and the soil is calcareous and its structure was destroyed 
excessively. This land was chosen deliberately and rolling was done after plantation.

After about 15 days of planting, there was a good rain there was a perfect output in every types. Until the earing period, the plant progress began to regress due to decreasing rains and these decreasing rains in grain forming period have affected the productivity of all cultivars negatively. The experiment was harvested with parcel combine harvester on 11.05.2009.

In terms of rainfall during growing season, the second disadvantageous region is Turkmenkoy. Also, the obtained yield illustrates this openly. Great differences in terms of yield between variables are observed. On this location, the highest yield is obtained from Pewter with $162 \mathrm{~kg}$ yield decare, and then Athenais and Nure the followers of it. Again among these types; the earliest type is Athenais and latest is Fouga. Despite all the applications such as foreign plant control and tillage were in the optimum level, Turkmenkoy with $118 \mathrm{~kg} / \mathrm{da}$ grain yield has been the location with the lowest average yield. It is obvious that; this is caused by bad soil conditions, rain amount and distribution on the plant growing period completely.

\section{Tepebasi}

The planting of experiment was done on 10.12.2009 with a grain drill and harvested on 01.06.2009. As can be seen the graph below, the obtained grain yield for all cultivars are above the country average and the average yield of this location is $233 \mathrm{~kg} / \mathrm{da}$.

Despite the antecedent precipitation and differences of soil structure, the performances of cultivars are similar to Turkmenkoy. While the highest yield in Tepebasi is obtained from Nurecultivar with $310 \mathrm{~kg} / \mathrm{da}$, Pewter $(283 \mathrm{~kg} / \mathrm{da}) \mathrm{has}$ been the follower of it whereas the Athenais has been on the $4^{\text {th }}$ line.

In case the environment becomes more convenient in terms of soil and climate; some cultivars which have high yield potential in good environment have become prominent. However; the types which have good performance in weak environment have dragged.

\section{Kumkoy}

This study was held in Kumkoy; a land $2 \mathrm{~km}$ far from the sea, very salty and previously hesperidium planting was done. However; the salinity was observed as not having a significant effect on barley.

The experiment was planted on 18.12.2009 with a grain driller and harvested on 13.05.2009.

Regarding the precipitation amount and soil conditions; the highest yields in all cultivars were obtained from this location. The average yield of the location is $304 \mathrm{~kg} / \mathrm{da}$. The highest yield is obtained from Nure cultivar with $410 \mathrm{~kg} / \mathrm{da}$ and however the Pewter which had shown highest yields other locations has been on the second line with its $400 \mathrm{~kg} / \mathrm{da}$ yield. Athenais on the other hand, has been on the fifth line with its $240 \mathrm{~kg} / \mathrm{da}$ yield. 
This experiment held in Kumkoy is a proof for obtaining very high yields in even one year from barley on the condition that using most suitable types for ecology.

\section{Haspolat}

On this field where it is close to water treatment unit of the municipality in Haspolat, planting was done with a grain driller on the 09.01.2009 and harvested on 11.05.2009.

Haspolat region is also the less rained land during plant growing period so; compared to other locations relatively, even though it has better soil conditions the grain yields here has been in very low level with $146 \mathrm{~kg} / \mathrm{da}$. The highest yield on this location is obtained from Nure cultivar with $185 \mathrm{~kg} / \mathrm{da}$ and Pewter and Otis respectively. Athenais however has been on the fifth line.

\section{General Evaluation of the Locations}

The performances of types used in the experiment in different locations are given on the table below.

Table 4. The yields of cultivars in the experiments in different locations

\begin{tabular}{|c|c|c|c|c|c|}
\hline & Turkmenkoy & Tepebasi & Kumkoy & Haspolat & Average \\
\cline { 2 - 6 } & $\begin{array}{c}\text { Yield } \\
\mathrm{kg} / \mathrm{da}\end{array}$ & $\begin{array}{c}\text { Yield } \\
\mathrm{kg} / \mathrm{da}\end{array}$ & $\begin{array}{c}\text { Yield } \\
\mathrm{kg} / \mathrm{da}\end{array}$ & $\begin{array}{c}\text { Yield } \\
\mathrm{kg} / \mathrm{da}\end{array}$ & $\begin{array}{c}\text { Yield } \\
\mathrm{kg} / \mathrm{da}\end{array}$ \\
\hline Otis & $113 \mathrm{1-k}$ & $205 \mathrm{~d}$ & $308 \mathrm{~b}$ & $170 \mathrm{f}$ & $\mathbf{1 9 9 . 0}$ \\
\hline Nure & $140 \mathrm{gh}$ & $310 \mathrm{~b}$ & $410 \mathrm{a}$ & $185 \mathrm{ef}$ & $\mathbf{2 6 1 . 4}$ \\
\hline Athenais & $142 \mathrm{gh}$ & $200 \mathrm{de}$ & $240 \mathrm{c}$ & $120 \mathrm{~h}-\mathrm{j}$ & $\mathbf{1 7 5 . 4}$ \\
\hline Prestige & $92 \mathrm{k}$ & $157 \mathrm{fg}$ & $245 \mathrm{c}$ & $138 \mathrm{~g}-1$ & $\mathbf{1 5 8 . 0}$ \\
\hline Pewter & $162 \mathrm{fg}$ & $283 \mathrm{~b}$ & $400 \mathrm{a}$ & $155 \mathrm{fg}$ & $\mathbf{2 5 0 . 0}$ \\
\hline Fouga & $61 \mathrm{118.3}$ & $240 \mathrm{c}$ & $219 \mathrm{~cd}$ & $105 \mathrm{jk}$ & $\mathbf{1 5 6 . 2}$ \\
\hline Average & $\mathbf{2 3 2 . 5}$ & $\mathbf{3 0 3 . 7}$ & $\mathbf{1 4 5 . 5}$ & $\mathbf{2 0 0 . 0}$ \\
\hline CV $(\%): 8.2$ Lsd $(0.05) ;$ Cultivar:13.5, Location: 11.0, Cultivar x Location: 26.9 \\
\hline
\end{tabular}

When the experiments are evaluated statistically; the effects of genotype, environment and genotype $\mathrm{x}$ environment interaction were significant at $1 \%$ level of probability for grain yield. While the highest grain yield is in Kumkoy location with Nure $(410 \mathrm{~kg} / \mathrm{da})$ and Pewter $(400 \mathrm{~kg} / \mathrm{da})$ types, the lowest grain yield is in Turkmenkoy location with Fouga $(61 \mathrm{~kg} / \mathrm{da})$ type.

When the locations are considered; the highest average yield is from Kumkoy with $304 \mathrm{~kg} / \mathrm{da}$ and the lowest average yield is from Turkmenkoy with $118 \mathrm{~kg} / \mathrm{da}$. This difference is mainly caused by precipitation and distribution as well as subsidiary factors such as soil structure, etc.

When evaluating the types used in the experiments; the highest yield is obtained from Nure type with $261 \mathrm{~kg} / \mathrm{da}$ according to average of grain yield in all locations and then respectively, Pewter $250 \mathrm{~kg}$. and Athenais with $176 \mathrm{~kg} / \mathrm{da}$ as 
on the $4^{\text {th }}$ line. The obtained results of Degirmenci et al., 2014 have shown similar results of the Degirmenci and Varoglu 2015 and Serinay et al.,2013 and Akerzurumlu 2014. However; these obtained results are found to be lower than Kirtok etal., 2001 results.

Although the results are for one year, while evaluating all cultivars and locations in this study can be said to be hint for barley agriculture.

\section{CONCLUSIONS}

Since the main limit in dry farming is water, the water efficiency of the cultivars used is expected to be high. Even the Athenais is used broadly and has more performance in weak and less rained environments; using this cultivar in the country in general is not a right choice. Giving advice according to the environment will provide better yields in normal rained years and better environments from the high potential cultivars and will make barley farming more economic.

Eliminating the effects of drought completely might be impossible with today's technology. However; spreading a science based farming in the system and minimizing the effects of drought should be the main target. With this regards; adding different variables to the production for different ecological zones of the country is possible and also integrating agronomic techniques which increase the water use efficiency makes barley farming more economic possible.

\section{REFERENCES}

Akerzurumlu E. (2004). A Study On Determining The Suitable Nitrogen Rate and Sowing Density For Barley In Cyprus conditions. M.Sc. (Agri.) Thesis, University of Cukurova, Adana.

Degirmenci et al.(2014). A Research On Yield And Yield Components Of Some Barley Cultivars. Scientific Conference. Challenges in Modern Agricultural Production, December 11, 2014, Skopje.

Değirmenci, R., Varoğlu H.(2015). A Research On Yield And Yield Components Of Some Barley Cultivars In The Mesoria Plain. 2nd Inner Anatolia region of agriculture and food congress, 28-30 April 2015, Nevsehir.

FAO (2011). Statistical database. http://www.fao.org.Accesed on 07/08/2011

Statistics and Planning Division (2010). Agricultural Structure and Production 2010.The Ministry of Agriculture and Forestry. Nicosia.

Statistics and Planning Division (2011).Agricultural Structure and Production2011.The Ministry of Agriculture and Forestry. Nicosia.

Kirtok et al. (2001).Investigation To Determine High Yielded Barley Cultivars In Irrigation Conditions Of Turkish Republic Of Northern Cyprus. The $4^{\text {th }}$ Field Crops Congress, 17-21 September 2001, Tekirdag.s:147-150.

Serinay et al. (2013).Response of Three Barley Cultivars (Hordeum vulgare L.) to Various Nitrogen Rates In The Mesoria Plain. International Agriculture Congress, 26-29 September 2013, Antalya. 